\title{
PENGARUH PROFITABILITAS TERHADAP NILAI PERUSAHAAN DENGAN CORPORATE SOCIAL RESPONSIBILITY SEBAGAI VARIABEL MODERASI
}

\author{
Ni Kadek Raningsih ${ }^{1}$ \\ Luh Gede Sri Artini ${ }^{2}$ \\ ${ }^{1,2}$ Fakultas Ekonomi dan Bisnis Universitas Udayana, Bali, Indonesia \\ e-mail:nikadekraningsih@ rocketmail.com
}

\begin{abstract}
ABSTRAK
Penelitian ini bertujuan untuk menguji kembali pengaruh variabel profitabilitas yang diproksikan dengan ROA terhadap nilai perusahaan yang diproksikan dengan PBV dengan CSR (ekonomi, lingkungan, sosial) sebagai variabel moderasi. Populasi dalam penelitian ini adalah perusahaan manufaktur di Bursa Efek Indonesia pada periode 2013-2016. Penentuan sampel menggunakan metode nonprobabilitas dengan teknik purposive sampling dan diperoleh sebanyak 12 perusahaan manufaktur dengan total amatan sebanyak 48. Teknik analisis yang digunakan adalah analisis regresi moderasi. Hasil penelitian ini menunjukkan bahwa profitabilitas berpengaruh positif terhadap nilai perusahaan. CSR Ekonomi dan Sosial memperlemah pengaruh profitabilitas terhadap nilai perusahaan, sedangkan CSR Lingkungan tidak mampu memoderasi pengaruh profitabilitas terhadap nilai perusahaan. Implikasi praktis yang dapat diberikan dari temuan penelitian ini adalah kajian ini dapat dijadikan acuan dasar dalam memotivasi perusahaan untuk lebih meningkatkan total aset perusahaan karena aset menunjukkan aktiva yang digunakan untuk aktivitas operasional perusahaan yang dapat meningkatkan profitabilitas sehingga mampu meningkatkan nilai perusahaan.
\end{abstract}

Kata kunci: nilai perusahaan, profitabilitas, corporate social responsibility.

\begin{abstract}
The result of this study indicates that profitability has positive effect on the corporate value. Economic and Social CSR weaken the effect of probability on the corporate value; meanwhile Environmental CSR was not able to moderate the influence of probability on the corporate value.The population in this study is manufacturing company in Indonesia Stock Exchange in the period 2013-2016. Non-probability method was used as sample determination with purposive sampling technique and 12 manufacturing companies was obtained with total observation of 48. Analysis technique that was used is moderation regression analysis. The practical implication that can be given from the findings of this study is that, this study can be the baseline in motivating the company to improve the total assets of the company because assets show the assets used for the company's operational activities that can improve profitability therefore can increase the corporate value.
\end{abstract}

Keywords: corporate value, profitability, corporate social responsibility. 


\section{PENDAHULUAN}

Manajemen perusahaan memiliki tujuan utama yaitu memaksimalkan nilai perusahaan, mencapai keuntungan perusahaan yang maksimal serta memakmurkan pemilik dan pemegang saham (Timbulengdkk.,2015). Nilai perusahaan menggambarkan pandangan investor terhadap tingkat keberhasilan dari suatu perusahaan yang tercermin dari harga saham. Semakin tinggi harga saham suatu perusahaan, maka akan semakin tinggi juga kemakmuran para pemegang sahamnya (Nurlela dan Islahuddin, 2008). Semakin banyak investor yang tertarik berinvestasi, maka semakin meningkat pula nilai perusahaan (Mukhtaruddin dkk., 2014).Menurut Ika dan Shidiq (2013) nilai perusahaan adalah nilai yang mencerminkan berapa harga yang bersedia dibayar oleh investor untuk suatu perusahaan.Nilai perusahaan sangat penting karena mencerminkan kinerja perusahaan yang dapat mempengaruhi minat investor untuk berinvestasi.

Menurut Afzal (2012) Price to Book Value (PBV) menggambarkan seberapa besar pasar menghargai nilai buku saham suatuperusahaan. Semakin tinggi rasio ini, berarti pasar percaya akan prospek perusahaantersebut. Salah satu cara untuk memaksimalkan nilai perusahaan adalah melalui profitabilitas (Setiabudi dkk.,2012). Nilai perusahaan akan mampu meningkat apabila kinerja perusahaan semakin baik. Salah satu faktor yang dapat mencerminkan kinerja perusahaan yang baik adalah rasio profitabilitas perusahaan (Anwar dkk., 2010). Profitabilitas sangat penting untuk perusahaan dalam rangka mempertahankan kelangsungan usahanya, hal ini dikarenakan profitabilitas menunjukkan apakah perusahaan mempunyai prospek yang baik di masa yang akan datang atau 
tidak(Sumiatidkk., 2013). Menurut Kasmir (2015:199) profitabilitas merupakan faktor yang dapat mempengaruhi nilai perusahaan. Apabila manajer mampu mengelola perusahaan dengan baik maka biaya yang akan dikeluarkan oleh perusahaan akan menjadi lebih kecil sehingga laba yang dihasilkan perusahaan menjadi lebihbesar yang akan mempengaruhi meningkatnya harga saham sehingga mampu meningkatkan nilai perusahaan (Jogiyanto, 2013).

Penelitian ini menggunakan return on asset (ROA) sebagai alat ukur dari rasio profitabilitas. Rasio ROA membandingkan laba bersih yang diperoleh perusahaan dengan total aset yang dimiliki perusahaan. ROA menggambarkan kemampuan suatu perusahaan memperoleh laba dari sumber daya atau asset yang dimiliki perusahaan (Maryam,2012). Penelitian ini menggunakan rasio ROA untuk mengukur profitabilitas perusahaan manufaktur karena karakteristik perusahaan manufaktur dalam kegiatan operasionalnya menggunakan asset berupa mesin pabrikasi sehingga keuntungan perusahaan diperoleh dari asset perusahaan.

Menurut penelitian dari Ika dkk., (2013), Anggitasari (2017) dan Febriana (2016), serta Pratama(2016)menyatakan bahwa profitabilitas berpengaruh positif terhadap nilai perusahaan. Hasil penelitian tersebut menjadi tidak konsisten dengan penelitian dari Putra (2013), Munawaroh (2014), Triagustina (2015), Sukarmanto(2015), dan Helliana (2015) serta Crisostomo et al., (2012) yang menyatakan bahwa profitabilitas tidak memiliki pengaruh yang signifikan terhadap terhadap nilai perusahaan. Berdasarkan penelitian sebelumnya terdapat perbedaan atau ketidakkonsistenan hasil penelitian sebelumnya tentang pengaruh profitabilitas terhadap nilai perusahaan, maka variabel pengungkapan Corporate 
Social Responsibility (CSR) dipilih sebagai variabel moderasi yang di duga mampu memperkuat atau memperlemah pengaruh profitabilitas terhadap nilai perusahaan.

Perusahaan mempunyai beberapa kewajiban yang harus dipenuhi, kewajiban tersebut tidak hanya kepada para pemegang saham, namun juga kewajiban terhadap pihak lain termasuk masyarakat. Semakin besar kepedulian perusahaan pada masyarakat yang tercermin dalam Corporate Social Responsibility (CSR) dan mengungkapkannya dalam pelaporan perusahaan, maka semakin besar pengaruh positifnya terhadap kinerja keuangan dan nilai perusahaan (Lako, 2010:85).Perusahaan dituntut untuk tidak hanya memberikan kontribusi terhadap pertumbuhan ekonomi saja, tetapi juga dapat membantu dalam memecahkan permasalahan terkait risiko dan ancaman terhadap keberlanjutan (sustainability) dalam lingkup hubungan sosial, lingkungan, dan perekonomian (GRI, 2006).

Corporate Social Responsibility (CSR) merupakan sebuah gagasan yang menitikberatkan tanggung jawab perusahaan pada keseimbangan antara perhatian terhadap aspek ekonomis, sosial, dan lingkungan atau triple bottom lines (Untung, 2015). CSR dimaksudkan agar dunia usaha meminimalisir dampak buruk terhadap aspek sosial dan lingkungan yang ditimbulkan selama menjalankan seluruh aktivitasnya. Penerapan CSRdapat meminimalisir kemungkinan perusahaan tidak diterima oleh lingkungannya sehingga akan berdampak pada kegiatan operasional perusahaan. 
CSR sebagai variabel moderasi telah banyak dilakukan oleh peneliti sebelumnya, namun hasil penelitian tersebut memberikan hasil yang bias karena penelitian sebelumnya menggunakan variabel CSR tersebut dengan menggabungkan ketiga aspek yaitu ekonomi, lingkungan dan sosial. Penelitian ini berbeda dengan penelitian lainnya, yaitu penelitian ini menggunakan CSR sebagai variabel moderasi dengan membagi variabel CSR menjadi tiga variabel berdasarkan Global Reporting Index (GRI)yaitu CSR aspek ekonomi, lingkungandan sosial. CSR aspek ekonomi mencerminkan bagaimana perusahaan mampu menghasilkan dan mendistribusikan, serta meningkatkan nilai ekonomi sehingga berdampak pada keadaan ekonomi bagi masyarakat. CSR aspek lingkungan mencerminkan tanggung jawab perusahaan terhadap dampak lingkungan yang dihasilkan dari kegiatan operasional perusahaan. CSR aspek sosial menunjukkan tanggung jawab sosial perusahaan yang berdampak pada kesehatan dan keselamatan karyawan serta masyakat lokal.

Berdasarkan penelitian sebelumnya dari Wijayadkk.,(2015), Wulandari dkk., (2017) dan Putri dkk., (2015) serta Hau et al.,(2017) menemukan bahwa pengungkapan CSR mampu memoderasi pengaruh kinerja keuangan terhadap nilai perusahaan.Hasil penelitian tersebut tidak konsisten dengan penelitian Rahayu (2010) dan Deriyarso (2014) yang menunjukkan hasil bahwa pengungkapan CSR tidak mampu memoderasi pengaruh antara Kinerja Keuangan dengan Nilai Perusahaan.Berdasarkan perbedaan hasil penelitian sebelumnya yang tidak konsisten, maka penelitian ini ingin membuktikan pengaruh profitabilitas terhadap nilai perusahaan dengan CSR sebagai variabel 
moderasi.Penelitian ini juga dilakukan untuk mengetahui diantara ketiga aspek CSR tersebut yang mana mampu memperkuat atau memperlemah pengaruh profitabilitas terhadap nilai perusahaan. Memperkuat atau memperlemah hasil dari ketiga aspek CSR (ekonomi, lingkungan dan sosial) dapat memberikan informasi bagi manajemen perusahaan, untuk meningkatkan pelaksanaan tanggung jawab sosial pada aspek yang kurang berdampak pada karyawan, masyarakat dan lingkungan perusahaan, sehingga perusahaan mengoptimalkan pelaksanaan CSR dan tetap mengikuti kebijakan pemerintah mengenai pengungkapan tanggung jawab sosial.

Salah satu sektor industri yang menarik untuk diteliti adalah sektor manufaktur.Perusahaan manufaktur dipilih sebagai objek penelitian karena perusahaan manufaktur lebih mudah terpengaruh oleh kondisi ekonomi dan memiliki tingkat sensitifitas yang tinggi terhadap setiap kejadian baik internal maupun eksternal perusahaan.Perusahaan manufaktur juga sangat terkait dengan lingkungan dan masyarakat (Deriyarso, 2014).Perusahaan manufaktur adalah perusahaan yang mengolah barang mentah menjadi barang jadi atau setengah jadi, sehingga menambah nilai dari barang tersebut.Sampel yang digunakan dalam penelitian ini yaitu perusahaan manufaktur yang terdaftar di Bursa Efek Indonesia (BEI) pada tahun 2013-2016.

Adapun rumusan masalah dalam penelitian ini adalah 1) Apakah profitabilitas berpengaruh positif dan signifikan terhadap nilai perusahaan? 2) Apakah CSR ekonomi mampu memoderasi pengaruh profitabilitas terhadap nilai perusahaan? 3) Apakah CSR lingkungan mampu memoderasi pengaruh 
profitabilitas terhadap nilai perusahaan? 4) Apakah CSR social mampu memoderasi pengaruh profitabilitas terhadap nilai perusahaan?

Zuraedah (2010) menyatakan bahwa nilai perusahaan merupakan tolak ukur yang penting bagi pasar atau calon investor sebagai gambaran kinerja dari perusahaan. Nilai perusahaan menjadi tolak ukur kinerja perusahaan sekaligus dapat menjadi acuan terhadap prospek atau kinerja perusahaan di masa depan. Peningkatan nilai sebuah perusahaan menandakan perusahaan telah berprestasi dan akan terlihat dari kenaikan harga saham perusahaan, selain itu peningkatan nilai perusahaan juga mengindikasikan kesejahteraan para pemegang saham juga akan meningkat. Perusahaan selalu berupaya dan berkinerja dengan maksimal dalam rangka untuk meningkatkan nilai perusahaannya yang tercermin dari peningkatan harga sahamnya (Priatinah dan Kusuma, 2012).Faktor pendorong perusahaan untuk meningkatkan nilai perusahaannya sangat menarik untuk diteliti. Beberapa dari faktor tesebut antara lain: profitabilitas, CSR ekonomi, CSR lingkungan dan CSR sosial.

Berbagai kebijakan yang diambil manajemen dalam upaya untuk meningkatkan nilai perusahaan melalui peningkatan kemakmuran pemilik dan para pemegang saham yang tercermin pada harga saham. Kondisi tersebut membuat investor akan berkepentingan dengan menganalisis nilai perusahaan, sebab analisis nilai perusahaan akan memberikan kebermanfaatan informasi kepada investor dalam menilai prospek perusahaan di masa mendatang dalam menghasilkan laba. Penelitian yang dilakukan oleh Dilling (2009), Sumiati (2013) dan Yuliani (2014) mendapatkan hasil bahwa profitabilitas secara 
signifikan berpengaruh positif terhadap nilai perusahaan.Berdasarkan penelitian tersebut, hipotesis yang dapat diajukan untuk mengetahui pengaruh profitabilitas terhadap nilai perusahaan adalah sebagai berikut:

\section{$\mathrm{H}_{1}$ : Profitabilitas berpengaruh positif dan signifikan terhadap nilai perusahaan. \\ Tingginya minat investor untuk menanamkan modalnya pada perusahaan} dengan ROA yang tinggi akan meningkatkan harga saham. Maka, akan terjadi hubungan positif antara profitabilitas dengan harga saham dimana tingginya harga saham akan mempengaruhi nilai perusahaan. Menurut Bowman dan Haire (1976);serta Preston (1978) dan Milne (1996), semakin tinggi tingkat profitabilitas perusahaan maka semakin besar pengungkapan informasi sosial yang dilakukan perusahaan. Corporate SocialResponsibility akan meningkatkan nilai perusahaan pada saat profitabilitas perusahaan meningkat. Hasil penelitian Dahlia dan Siregar (2008) juga mengindikasikan bahwa perilaku etis perusahaan berupa tanggung jawab sosial terhadap lingkungan sekitarnya memberikan dampak positif, yang dalam jangka panjang akan tercermin pada keuntungan perusahaan (profit) dan peningkatan kinerja keuangan. Penelitian yang dilakukan oleh Pramana (2016), Ekowati (2014) dan Yuniasih (2007) mendapatkan hasil bahwa CSR mampu memoderasi pengaruh profitabilitas terhadap nilai perusahaan.Berdasarkan penjelasan tersebut dirumuskan hipotesis sebagai berikut.

\section{H2 : CSREkonomi memoderasipengaruh Profitabilitas terhadap Nilai Perusahaan}

Semakin baik pertumbuhan profitabilitas berarti prospek perusahaan di masa depan dinilai semakin baik juga, artinya semakin baik pula nilai perusahaan 
dimata investor. Apabila kemampuan perusahaan untuk menghasilkan laba meningkat, maka harga saham juga akan meningkat (Jogiyanto, 2013:317). Harga saham yang meningkat mencerminkan nilai perusahaan yang baik bagi investor. Sudarma (2004) menyatakan bahwa nilai pemegang saham akan meningkat apabila nilai perusahaan meningkat yang ditandai dengan tingkat pengembalian investasi yang tinggi kepada pemegang saham. Tingkat pengembalian investasi kepada pemegang saham tergantung pada laba yang dihasilkan perusahaan. Oktaviani (2008) juga menyatakan bahwa dengan tingginya tingkat laba yang dihasilkan, berarti prospek perusahaan untuk menjalankan operasinya di masa depan juga tinggi sehingga nilai perusahaan yang tercermin dari harga saham perusahaan akan meningkat pula. Penelitian yang dilakukan oleh Dahlia dkk., (2008) , Ramdana (2017), dan Rakhiemah dkk., (2009) mendapatkan hasil bahwa CSR mampu memoderasi pengaruh profitabilitas terhadap nilai perusahaan.Berdasarkan penjelasan tersebut dirumuskan hipotesis sebagai berikut.

\section{H3 : CSR Lingkungan memoderasipengaruh Profitabilitas terhadap Nilai Perusahaan}

Pelaksanaan CSR diharapkan akan mampu menaikkan nilai perusahaan dilihat dari harga saham dan laba perusahaan (earning) sebagai akibat dari para investor yang menanamkan saham di perusahaan, karena kegiatan CSR merupakan keberpihakan perusahaan terhadap masyarakat. Masyarakat akan mampu memilih produk yang baik yang di nilai tidak hanya barangnya saja, tetapi juga melalui tata kelola perusahaannya. Kegiatan CSR sendiri merupakan bagian dari tata kelola perusahaan yang baik. Pada saat masyarakat yang menjadi pelanggan memiliki penilaian yang positif terhadap perusahaan, maka mereka 
akan loyal terhadap produk yang dihasilkan. Hal ini akan mampu menaikkan citra perusahaan yang direfleksikan melalui harga saham yang akan meningkat.Penelitian yang dilakukan oleh Utami (2011), Hidayansyah(2015) dan Munawaroh (2014) mendapatkan hasil bahwa CSR mampu memoderasi pengaruh profitabilitas terhadap nilai perusahaan.Berdasarkan penjelasan tersebut dirumuskan hipotesis sebagai berikut.

\section{H4 : CSR Sosial memoderasi pengaruh Profitabilitas terhadap Nilai Perusahaan}

\section{METODE PENELITIAN}

Data yang dapat digunakan dalam penelitian ini adalah data kualitatif dan data kuantitatif.Data kuantitatif yang dimaksud dalam penelitian ini adalah berupa angka dalam annual report, sedangkan data kualitatif dalam penelitian ini adalah berupa penjelasan berbentuk kalimat dalam annual report pada perusahaan Manufaktur di Bursa Efek Indonesia (BEI).

Berdasarkan sumbernya, data yang digunakan dalam penelitian ini adalah data sekunder.Data sekunder eksternal dalam penelitian ini adalah annual report perusahaan manufaktur yang terdaftar di BEI yang diperoleh melalui website resmi BEI.

Populasi dalam penelitian ini adalah seluruh perusahaan manufaktur yang terdaftar di BEI tahun 2013-2016.Sampel dalam penelitian ini adalah perusahaan manufaktur yang terdaftar di BEI tahun 2013-2016 yang memenuhi beberapa kriteria tertentu.Dengan ditetapkannya beberapa kriteria yang digunakan untuk menentukan jumlah sampel maka metode penentuan sampel dalam penelitian ini 
adalah metode nonprobability sampling dengan teknik purposive sampling.Kriteria-kriteria yang digunakan yaitu sebagai berikut 1) Perusahaan manufaktur yang memiliki nilai profitabilitas yang positif pada periode penelitian tahun 2013-2016. 2) Perusahaan manufaktur yang mempublikasikan laporan tahunan lengkap termasuk pengungkapan Corporate Social Responsibility dan tersedia untuk publik.

Berdasarkan kriteria tersebut, dapat dilihat jumlah sampel penelitian sebagai berikut.

Tabel 1.

Jumlah Sampel Penelitian

\begin{tabular}{clc}
\hline NO & \multicolumn{1}{c}{ KRITERIA } & JUMLAH \\
\hline 1 & Jumlah Perusahaan Manufakturdi BursaEfek & 144 \\
& Indonesiaperiode2013-2016. \\
2 & Jumlah perusahaan yang tidak memiliki nilai profitabilitas & $(45)$ \\
& yang positif periode penelitian tahun 2013-2016. \\
3 & Jumlah Perusahaanyang tidak mempublikasikan laporan \\
& tahunan lengkap termasuk pengungkapan CSR periode2013- & $(87)$ \\
& 2016. & \\
& Total Sampel & 12 \\
\hline
\end{tabular}

Sumber: Data diolah, 2017

Variabel independen dalam penelitian ini adalah profitabilitas(X)Variabel dependen yang digunakan dalam penelitian ini adalah nilai perusahaan (Y). Variabel moderasi dalam penelitian ini adalahCorporate Social Responsibility (M) yang dibagi menjadi tiga variabel yaitu: 1) CSR Ekonomi (M1), 2) CSR Lingkungan (M2), 3) CSR Sosial (M3).

Metode analisis data yang digunakan dalam penelitian ini adalah menggunakan Moderated Regression Analysis (MRA). Analisis moderasi dapat 
dilakukan dengan menggunakan program SPSS (Statistical Package for Social Science).Analisis ini digunakan untuk mengetahui pengaruh profitabilitas terhadap nilai perusahaan dengan CSR sebagai variabel moderating pada perusahaan manufaktur yang terdaftar di BEI periode 2013-2016.

\section{HASIL PENELITIAN}

Variabel yang digunakandalam penelitian ini adalah variabel independendan variabel dependen. Variabelprofitabilitas(X) dioperasikan sebagai variabel independen.Variabel nilai perusahaan (Y)dioperasikan sebagai variabel dependen dan variabelmoderasiadalah Corporate Social Responsibility Ekonomi (M1), Corporate Social Responsibility Lingkungan (M2), Corporate Social Responsibility Sosial (M3). Statistikdeskriptif masing-masing variabel dapat dilihat padaTabel 5.1berikut:

Tabel 2.

Statistik Deskriptif

\begin{tabular}{cccccc}
\hline & $\mathrm{N}$ & Maksimum & Minimum & Mean & Std. Deviation \\
\hline X & 48 & 40,180 & 0,330 & 13,76188 & 9,433053 \\
M1 & 48 & 0,330 & 0,110 & 0,19042 & 0,077924 \\
M2 & 48 & 0,210 & 0,020 & 0,07146 & 0,048333 \\
M3 & 48 & 0,100 & 0,020 & 0,05667 & 0,029846 \\
XM1 & 48 & 8,686 & 0,121 & 2,49726 & 1,804941 \\
XM2 & 48 & 4,738 & 0,066 & 1,06244 & 1,166826 \\
XM3 & 48 & 2,369 & 0,022 & 0,72961 & 0,514581 \\
Y & 48 & 58,480 & 0,830 & 9,40708 & 13,278936 \\
N Valid & 48 & & & & \\
\hline
\end{tabular}

Sumber : Data diolah, 2017

Berdasarkan Tabel 2. dapat dilihat bahwa variabelProfitabilitas(Y1)yang diproksikandenganReturnOnAsset (ROA)memilikinilai terendah(minimum) selama periode pengamatanyaitu1,100 yang artinya terdapat profit hingga mencapai $1,1 \%$ dari seluruh aset perusahaan.JumlahROAtertinggi(maksimum) selamaperiodepengamatanyaitu40,180, hal ini berarti perusahaan dapat 
menghasilkan laba bersih hingga $40,180 \%$ dari total asset yang dimiliki perusahaan dengan rata-rata hitung sebesar 13,76188artinyarata-rata profitabilitasmanufaktur di Bursa Efek Indonesia selama periode 20132016adalahsebesar13,76188. Nilai ini menunjukkan kemampuan perusahaan dalam menghasilkan laba dari total asset perusahaan.

VariabeNilai Perusahaan (Y)yang diproksikandenganPrice to Book Value (PBV)memilikinilai terendah(minimum) selama periode pengamatanyaitu0,830 yang artinya terdapat nilai perusahaan hingga mencapai $0,830 \%$ dari seluruh nilai pasar perusahaan.JumlahPBVtertinggi(maksimum) selamaperiodepengamatanyaitu58,480, hal ini berarti perusahaan dapat menghasilkan laba bersih hingga $58,480 \%$ dari nilai perusahaan yang dimiliki perusahaan dengan rata-rata hitung sebesar 9,40708 dengan nilai standar deviasi sebesar 13,278936, hal ini berarti rata-rata 9,40708 menunjukkan keberhasilan manajemen dalam mengelola operasional perusahaan sehingga kinerja perusahaan dikatakan baik.

Variabel CSR Ekonomi (M1) memilikinilai terendah(minimum) selama periode pengamatanyaitu0,110 yang artinya terdapat luas pengungkapan CSR Ekonomi mencapai 0,11 \% dari seluruh CSR Ekonomi perusahaan.JumlahCSR Ekonomitertinggi(maksimum) selamaperiodepengamatanyaitu0,330, dengan ratarata hitung sebesar 0,19042 dengan nilai standar deviasi sebesar 0,077924, hal ini berarti rata-rata 0,19042 menunjukkan luasnya pengungkapan CSR Ekonomi yang dilakukan perusahaan. 
Variabel CSR Lingkungan (M2) memilikinilai terendah(minimum) selama periode pengamatanyaitu0,020 yang artinya terdapat luas pengungkapan CSR Lingkungan mencapai $0,020 \%$ dari seluruh CSR Lingkungan perusahaan.JumlahCSR Lingkungantertinggi(maksimum) selamaperiodepengamatanyaitu0,210, dengan rata-rata hitung sebesar 0,07146 dengan nilai standar deviasi sebesar 0,048333 , hal ini berarti rata-rata 0,07146 menunjukkan luasnya pengungkapan CSR Lingkungan yang dilakukan perusahaan.

Variabel CSR Sosial(M3) memilikinilai terendah(minimum) selama periode pengamatanyaitu0,020 yang artinya terdapat luas pengungkapan CSR Sosial mencapai $\quad 0,020 \%$ dari seluruh CSR Sosial perusahaan.JumlahCSR Sosialtertinggi(maksimum) selamaperiodepengamatan yaitu0,100, dengan ratarata hitung sebesar 0,05667 dengan nilai standar deviasi sebesar 0,029846 , hal ini berarti rata-rata 0,05667 menunjukkan luasnya pengungkapan CSR Sosial yang dilakukan perusahaan.

Nilai terendah(minimum) variabel interaksi antara Profitabilitas dengan Corporate Social Responsibility (CSR) Ekonomi selama periode pengamatanyaitu0,121dan jumlahinteraksi antara Profitabilitas dengan Corporate Social Responsibility (CSR) Ekonomitertinggi(maksimum) selamaperiodepengamatanyaitu8,686, dengan rata-rata hitung sebesar 2,49726 dengan nilai standar deviasi sebesar 0,077924. Nilai rata-rata untuk variabel interaksi antara Profitabilitas dengan Corporate Social Responsibility (CSR) Ekonomi yaitu sebesar 2,49726 menunjukkan kemampuan Corporate Social 
Responsibility (CSR) Ekonomi dalam memperkuat atau memperlemah hubungan Profitabilitas dengan Nilai Perusahaan.

Nilai terendah(minimum) variabel interaksi antara Profitabilitas dengan Corporate Social Responsibility (CSR) Lingkungan selama periode pengamatanyaitu0,066 dan jumlahinteraksi antara Profitabilitas dengan Corporate Social Responsibility (CSR) Lingkungantertinggi(maksimum) selamaperiodepengamatanyaitu4,738, dengan rata-rata hitung sebesar 0,07146 dengan nilai standar deviasi sebesar 0,048333. Nilai rata-rata untuk variabel interaksi antara Profitabilitas dengan Corporate Social Responsibility (CSR) Lingkungan yaitu sebesar 0,07146 menunjukkan kemampuan Corporate Social Responsibility (CSR) Lingkungan dalam memperkuat atau memperlemah hubungan Profitabilitas dengan Nilai Perusahaan.

Nilai terendah(minimum) variabel interaksi antara Profitabilitas dengan Corporate Social Responsibility (CSR) Sosial selama periode pengamatanyaitu0,022 dan jumlahinteraksi antara Profitabilitas dengan Corporate Social Responsibility $\quad$ (CSR) Sosialtertinggi(maksimum) selamaperiodepengamatanyaitu2,369, dengan rata-rata hitung sebesar 0,05667 dengan nilai standar deviasi sebesar 0,029846. Nilai rata-rata untuk variabel interaksi antara Profitabilitas dengan Corporate Social Responsibility (CSR) Sosial yaitu sebesar 0,05667 menunjukkan kemampuan Corporate Social Responsibility (CSR) Sosial dalam memperkuat atau memperlemah hubungan Profitabilitas dengan Nilai Perusahaan.

Tabel 3. 


\begin{tabular}{lll}
\hline Uji Asumsi Klasik & Hasil Uji & Keterangan \\
Uji Normalitas & $\mathrm{p}(0,116) ;(0,055) ;(0,061)>$ & Berdistribusi normal \\
& 0,05 & \\
Uji Autokorelasi & $1,7206<1,755<2,2794$, & Tidak ada autokorelasi \\
& $1,7206<1,755<2,2794$, & \\
Uji Heteroskedastisitas & $1,7206<1,755<2,2794$, & \\
& $\mathrm{p}(0,056) ;(0,572) ;(0,255)>$ & Tidak terjadi \\
& 0,05, & heteroskedastisitas \\
& $\mathrm{p}(0,269) ;(0,669) ;(0,538)>$ & \\
& 0,05, & \\
& $\mathrm{p}(0,228) ;(0,485) ;(0,349)>$ & \\
& 0,05 & \\
\hline
\end{tabular}

Sumber: Data diolah, 2017

Hasil uji analisis regresi moderasi model pertama menunjukkan persamaan:

$$
\mathrm{Y}=-15,788+2,205 \mathrm{X}+66,766 \mathrm{M}_{1}-7,153 \mathrm{X} \cdot \mathrm{M}_{1}
$$

Dimana :

$$
\begin{aligned}
& \mathrm{Y}=\text { Nilai Perusahaan } \\
& \mathrm{X}=\text { Profitabilitas } \\
& \mathrm{M}_{1}=\text { CSR_Ekonomi } \\
& \mathrm{X} . \mathrm{M}_{1}=\text { Interaksi antara Profitabilitas dengan CSR Ekonomi }
\end{aligned}
$$

Persamaan analisis regresi moderasi menunjukkan arah dan besarnya pengaruh masing-masing variabel independen terhadap variabel dependen sebagai berikut :

1) $\quad \alpha=-15,788$ memiliki arti bahwa saat variabel bebas berada pada konstanta 0 , maka nilai perusahaan sebesar $-15,788$.

2) $\quad \beta_{1}=2,205$ memiliki arti bahwa saat profitabilitas meningkat sebesar satu satuan maka nilai perusahaan akan meningkat sebesar 2,205 satuan.

3) $\quad \beta_{2}=66,766$ memiliki arti bahwa saat CSR Ekonomi meningkat sebesar satu satuan maka nilai perusahaan akanmeningkatsebesar 66,766 satuan. 
4) $\mathrm{B}_{3}=-7,153$ memiliki arti bahwa saat interaksi antara profitabilitas dengan CSR Ekonomi meningkat sebesar satu satuan maka nilai perusahaan akanmenurun sebesar 7,153 satuan.

Hasil uji analisis regresi moderasi model kedua menunjukkan persamaan:

$$
\mathrm{Y}=-7,546+1,504 \mathrm{X}+25,242 \mathrm{M}_{2}-5,221 \mathrm{X} . \mathrm{M}_{2}
$$

Dimana :

$$
\begin{aligned}
& \mathrm{Y}=\text { Nilai Perusahaan } \\
& \mathrm{X}=\text { Profitabilitas } \\
& \mathrm{M}_{2}=\text { CSR_Lingkungan } \\
& \text { X.M } \mathrm{M}_{2}=\text { Interaksi antara Profitabilitas dengan CSR Lingkungan }
\end{aligned}
$$

Persamaan analisis regresi moderasi menunjukkan arah dan besarnya pengaruh masing-masing variabel independen terhadap variabel dependen sebagai berikut :

1) $\alpha=-7,546$ memiliki arti bahwa saat variabel bebas berada pada konstanta 0 , maka nilai perusahaan sebesar -7,546.

2) $\beta_{1}=1,504$ memiliki arti bahwa saat profitabilitas meningkat sebesar satu satuan maka nilai perusahaan akanmeningkat sebesar 1,504 satuan.

3) $\beta_{2}=25,242$ memiliki arti bahwa saat CSR Lingkungan meningkat sebesar satu satuan maka nilai perusahaan akanmeningkat sebesar 25,242 satuan.

4) $\mathrm{B}_{3}=-5,221$ memiliki arti bahwa saat interaksi antara profitabilitas dengan CSR Lingkungan meningkat sebesar satu satuan maka nilai perusahaan akanmenurun sebesar 5,221 satuan.

Hasil uji analisis regresi moderasi model ketiga menunjukkan persamaan:

$$
\mathrm{Y}=-5,725+1,657 \mathrm{X}+90,878 \mathrm{M}_{3}-17,582 \mathrm{X}^{\mathrm{M}} \mathrm{M}_{3}
$$


Dimana :

$$
\begin{aligned}
& \mathrm{Y}=\text { Nilai Perusahaan } \\
& \mathrm{X}=\text { Profitabilitas } \\
& \mathrm{M}_{3}=\mathrm{CSR} \text { Sosial } \\
& \mathrm{X} . \mathrm{M}_{3}=\text { Interaksi antara Profitabilitas dengan CSR Sosial }
\end{aligned}
$$

Persamaan analisis regresi moderasi menunjukkan arah dan besarnya pengaruh masing-masing variabel independen terhadap variabel dependen sebagai berikut :

1) $\alpha=-5,725$ memiliki arti bahwa saat variabel bebas berada pada konstanta 0 , maka nilai perusahaan sebesar $-5,725$.

2) $\beta_{1}=1,504$ memiliki arti bahwa saat profitabilitas meningkat sebesar satu satuan maka nilai perusahaan akanmeningkat sebesar 1,504 satuan.

3) $\beta_{2}=90,878$ memiliki arti bahwa saat CSR Sosial meningkat sebesar satu satuan maka nilai perusahaan akanmeningkat sebesar 90,878 satuan.

4) $\mathrm{B}_{3}=-17,582$ memiliki arti bahwa saat interaksi antara profitabilitas dengan CSR Sosial meningkat sebesar satu satuan maka nilai perusahaan akanmenurun sebesar 17,582 satuan.

Uji statistik t dilakukan untuk menunjukkan seberapa jauh pengaruh satu variabel independen secara individual dalam menerangkan variasi variabel dependen. Uji t dapat dilakukan dengan melihat nilai signifikansi t masing-masing variabel pada output hasil regresi menggunakan SPSS dengan significance level $0,05(\alpha=5 \%)$. Hasil output dapat dilihat pada Tabel 4.sebagai berikut: 
Tabel 4.

Output Signifikansi Uji t

Model Pertama

\begin{tabular}{cccc}
\hline Variabel & t hitung & Sig. t & Keterangan \\
\hline $\mathrm{X}$ & 5,361 & 0,000 & $\begin{array}{c}\text { Hipotesis } \\
\text { diterima }\end{array}$ \\
\hline $\mathrm{XM} 1$ & $-3,228$ & 0,002 & Hipotesis ditolak \\
\hline Sumber: Data diolah, 2017 & &
\end{tabular}

Hasil uji t dapat diinterpretasikan bahwa variabel Profitabilitas (X) secara positif memengaruhi nilai perusahaan $(\mathrm{Y})$ dan signifikan karena diperoleh nilai signifikansi tidak lebih dari 0,05 yaitu 0,000. Jadi terdapat hubungan antara Profitabilitas (X) dengan Nilai Perusahaan (Y). Hasil signifikansi uji t menunjukkan bahwa profitabilitas secara signifikan dapat meningkatkan nilai perusahaan, sehingga hipotesis yang menyatakan profitabilitas berpengaruh positif dan signifikan terhadap nilai perusahaan diterima. Hasil penelitian ini sejalan dengan penelitian yang dilakukan oleh Dilling (2009), Sumiati (2013), Yuliani (2014), Ika dkk.,(2013), Anggitasari (2012) dan Febriana (2016) serta Pratama (2016) yang menyatakan profitabilitas berpengaruh positif terhadap nilai perusahaan.

Interaksi antara Profitabilitas (X) dengan Corporate Social Responsibility Ekonomi (M1) secara negatif dan signifikan memengaruhi nilai perusahaan (Y) karena diperoleh nilai signifikansi kurang dari 0,05 yaitu 0,002. Hasil analisis dapat dinyatakan bahwa variabel Corporate Social Responsibility Ekonomi (M1) secara signifikan memperlemah pengaruh profitabilitas $(\mathrm{X})$ dengan nilai perusahaan (Y). Koefisien interaksi profitabilitas (X) dengan Corporate Social Responsibility Ekonomi (M1) yang bernilai negatif menunjukkan bahwa 
pelaksanaan Corporate Social Responsibility Ekonomi (M1) yang tinggi diimbangi dengan penggunaan profitabilitas yang semakin tinggi dapat mengalami penurunan nilai perusahaan. Hal tersebut terjadi dikarenakan pengungkapan CSR Ekonomi yang dilakukan perusahaan menyebabkan bertambahnya beban perusahaan sehingga profit yang dihasilkan semakin rendah. Investor menganggap informasi pengungkapan CSR tersebut akan menurunkan tingkat pembagian deviden karena laba perusahaan berkurang. Informasi tersebut menyebabkan investor tidak tertarik untuk menginvestasikan dananya pada suatu perusahaan, sehingga harga saham cenderung menurun dan berdampak pada menurunnya juga nilai perusahaan. Hasil penelitian tersebut sejalan dengan penelitian yang dilakukan oleh Prastuti dkk., (2015), Amanti (2012), dan Rasmiati (2002) yang menyatakan bahwa pengungkapan CSR tidak memoderasipengaruh kinerja keuangan terhadap nilai perusahaan.

Tabel 5. Output Signifikansi Uji t

Model Kedua

\begin{tabular}{cccc}
\hline Variabel & t hitung & Sig. t & Keterangan \\
\hline $\mathrm{X}$ & 3,123 & 0,003 & $\begin{array}{c}\text { Hipotesis } \\
\text { diterima }\end{array}$ \\
\hline $\mathrm{XM} 2$ & $-1,102$ & 0,277 & Hipotesis ditolak \\
\hline Sumber:Data Diolah, 2017 & &
\end{tabular}

Hasil uji t dapat diinterpretasikan bahwa variabel Profitabilitas (X) secara positif memengaruhi nilai perusahaan $(\mathrm{Y})$ dan signifikan karena diperoleh nilai signifikansi tidak lebih dari 0,05 yaitu 0,003. Jadi terdapat hubungan antara Profitabilitas (X) dengan Nilai Perusahaan (Y). Hasil signifikansi uji t menunjukkan bahwa profitabilitas secara signifikan dapat meningkatkan nilai 
perusahaan, sehingga hipotesis yang menyatakan profitabilitas berpengaruh positif dan signifikan terhadap nilai perusahaan diterima. Hasil penelitian ini sejalan dengan penelitian yang dilakukan oleh Dilling (2009), Sumiati (2013), Yuliani (2014), Ika dkk.,(2013), Anggitasari (2012) dan Febriana (2016) serta Pratama (2016) yang menyatakan profitabilitas berpengaruh positif terhadap nilai perusahaan.

Interaksi antara Profitabilitas (X) dengan Corporate Social Responsibility Lingkungan (M2) tidak signifikan memengaruhi nilai perusahaan (Y) karena diperoleh nilai signifikansi lebih dari 0,05 yaitu 0,277 . Hasil analisis dapat dinyatakan bahwa variabel Corporate Social Responsibility Lingkungan (M2) tidak memoderasi pengaruh profitabilitas $(\mathrm{X})$ dengan nilai perusahaan $(\mathrm{Y})$. CSR Lingkungan tidak mampu memoderasi pengaruh profitabilitas terhadap nilai perusahaan karena pelaksanaan CSR Lingkungan seperti penanaman pohon, pengolahan limbah, pengendalian emisi karbon dilingkungan perusahaan dan sebagainya tidak berdampak pada kesejahteraan investor. Hal ini menyebabkan investor tidak melakukan investasi pada suatu perusahaan dan tidak adanya peningkatan harga saham dan nilai perusahaan.

Hasil penelitian tersebut sejalan dengan penelitian yang dilakukan oleh Rahayu (2010) dan Wulandari (2017) yang menyatakan bahwa pengungkapan CSR tidak mampu memoderasi pengaruh kinerja keuangan terhadap nilai perusahaan. Mariani (2016) hasil penelitian menunjukkan bahwa good corporate governance dan corporate social responsibility tidak mampu memoderasi pengaruh likuiditas, solvabilitas, dan profitabilitas pada nilai perusahaan. 
Tabel 6.

Output Signifikansi Uji t

Model Ketiga

\begin{tabular}{cccc}
\hline Variabel & t hitung & Sig. t & Keterangan \\
\hline $\mathrm{X}$ & 5,638 & 0,000 & $\begin{array}{c}\text { Hipotesis } \\
\text { diterima }\end{array}$ \\
\hline $\mathrm{XM} 3$ & $-2,907$ & 0,006 & Hipotesis ditolak \\
\hline Sumber: & & &
\end{tabular}

Sumber:Data diolah, 2017

Hasil uji t dapat diinterpretasikan bahwa variabel Profitabilitas (X) secara positif memengaruhi nilai perusahaan $(\mathrm{Y})$ dan signifikan karena diperoleh nilai signifikansi tidak lebih dari 0,05 yaitu 0,000 . Jadi terdapat hubungan antara Profitabilitas (X) dengan Nilai Perusahaan (Y). Hasil signifikansi uji t menunjukkan bahwa profitabilitas secara signifikan dapat meningkatkan nilai perusahaan, sehingga hipotesis yang menyatakan profitabilitas berpengaruh positif dan signifikan terhadap nilai perusahaan diterima.

Interaksi antara Profitabilitas (X) dengan Corporate Social Responsibility Sosial (M3) secara negatif dan signifikan memengaruhi nilai perusahaan (Y) karena diperoleh nilai signifikansi kurang dari 0,05 yaitu 0,006. Hasil analisis dapat dinyatakan bahwa variabel Corporate Social Responsibility Sosial (M3) secara signifikan memperlemah pengaruh profitabilitas $(\mathrm{X})$ dengan nilai perusahaan (Y). Koefisien interaksi profitabilitas (X) dengan Corporate Social Responsibility Sosial (M3) yang bernilai negatif menunjukkan bahwa pelaksanaan Corporate Social Responsibility Sosial (M3) yang tinggi diimbangi dengan penggunaan profitabilitas yang semakin tinggi dapat mengalami penurunan nilai perusahaan. Kedudukan CSR Sosial disini memperlemah hubungan profitabilitas terhadap nilai perusahaan.CSR Sosial tidak diperhatikan oleh investor sebagai 
dasar dalam pengambilan keputusan untuk melakukan investasi pada suatu perusahaan. Pelaksanaan CSR Sosial seperti kegiatan donor darah, bantuan pendidikan melalui beasiswa, pemberian bantuan alat-alat kesehatan dan sebagainya tidak berdampak pada kesejahteraan investor. Karena pelaksanaan CS RSosial tersebut menyebabkan bertambahnya beban perusahaan, sehingga menurunkan profitabilitas perusahaan yang berdampak pada penurunan pembagian dividen bagi investor. Hasil penelitian tersebut sejalan dengan penelitian yang dilakukan oleh Deriyarso (2014), Rahayu (2010), dan Dwijayanti (2012) yang menyatakan bahwa pengungkapan Corporate Social Responsibilitymemperlemah pengaruh kinerja keuangan terhadap nilai perusahaan. Hasil yang sama juga diperoleh pada penelitian Caroline (2013), dan Zuhroh dkk.,(2003), Post et al.,(2002), Corporate Social Responsibilitytidak mampu memoderasi pengaruh profitabilitas terhadap nilai perusahaan.

Pengujian koefisien determinasi dilakukan untuk mengetahui seberapa besar sumbangan yang diberikan variabel independen terhadap variabel dependen.Pada penelitian ini nilai koefisien determinasi yang digunakan adalah $R$ square.Penggunaan $R$-square sebagai salah satu indikator untuk mengetahui pengaruh pertambahan suatu variabel independen ke dalam suatu persamaan regresi.

Hasil analisis model pertama menunjukkan bahwa nilai $R$-square yaitu sebesar 0,580 yang menandakan bahwa $58 \%$ perubahan nilai perusahaan disebabkan oleh Profitabilitas,dan interaksi antara Profitabilitas dengan 
Corporate Social ResponsibilityEkonomi, sedangkan $42 \%$ dipengaruhi oleh variabel lain diluar penelitian ini.

Hasil analisis model kedua menunjukkan bahwa nilai $R$-square yaitu sebesar 0,610 yang menandakan bahwa $61 \%$ perubahan nilai perusahaan disebabkan oleh Profitabilitas, dan interaksi antara Profitabilitas dengan Corporate Social Responsibility Lingkungan, sedangkan 39\% dipengaruhi oleh variabel lain diluar penelitian ini.

Hasil analisis menunjukkan bahwa nilai $R$-square yaitu sebesar 0,580 yang menandakan bahwa $58 \%$ perubahan nilai perusahaan disebabkan oleh Profitabilitas, dan interaksi antara Profitabilitas dengan Corporate Social Responsibility Sosial, sedangkan $42 \%$ dipengaruhi oleh variabel lain diluar penelitian ini.

\section{SIMPULAN DAN SARAN}

Berdasarkan pada hasil penelitian maka di peroleh simpulan yaitu profitabilitas berpengaruh positif dan signifikan terhadap nilai perusahaan. Semakin tinggi profit yang diperoleh perusahaan maka akan semakin tertarik investor untuk berinvestasi sehingga harga saham meningkat dan nilai perusahaan juga meningkat.

CSR Ekonomi dapat memperlemah pengaruh profitabilitas terhadap nilai perusahaan. Semakin tinggi CSR Ekonomi yang dilakukan perusahaan menyebabkan bertambahnya beban perusahaan, sehingga menurunkan 
profitabilitas perusahaan yang berdampak pada penurunan pembagian dividen bagi investor, dan menurunkan minat investor melakukan investasi.

CSR Lingkungan tidak mampu memoderasi pengaruh antara profitabilitas terhadap nilai perusahaan. CSR lingkungan yang dilakukan perusahaan tidak berdampak pada kesejahteraan investor. Hal ini menyebabkan investor tidak melakukan investasi pada suatu perusahaan dan tidak adanya peningkatan harga saham dan nilai perusahaan.

CSR Sosial dapat memperlemah pengaruh profitabilitas terhadap nilai perusahaan.CSR Sosial yang dilakukan perusahaan memberikan sinyal negatif bagi investor, sehingga tidak adanya peningkatan harga saham dan nilai perusahaan.

Berdasarkan pada hasil penelitian maka diusulkan saran yaitu tingkat profitabilitas yang tinggi dapat dijadikan perusahaan sebagai komponen dasar dalam meningkatkan nilai perusahaan. Karena investor cenderung melihat profitabilitas yang dihasilkan oleh perusahaan sebagai dasar pengambilan keputusan dalam menginvestasikan dananya pada suatu perusahaan, sehingga perusahaan diharapkan meningkatkan profitabilitas. Selain hal tersebut sebaiknya perusahaan melaksanakan kegiatan CSR dilingkungan domisili investor, sehingga investor dapat secara langsung mengetahui pelaksanaan CSR yang dilakukan pada suatu perusahaan.

Sebaiknya investor lebih memperhatikan faktor fundamental seperti profitabilitas dalam pengambilan keputusan untuk melakukan investasi pada suatu 
perusahaan. Karena profitabilitas yang tinggi menunjukkan kinerja manajemen dalam perusahaan tersebut baik.

Berdasarkan hasil analisis uji $R$-Square terdapat $42 \%$ variasi diluar model yang mempengaruhi nilai perusahaan. Penelitian selanjutnya diharapkan meneliti variabel lain yang diprediksi dapat mempengaruhi nilai perusahaan seperti pertumbuhan perusahaan, ukuran perusahaan, leveragedan lain sebagainya. Memperluas populasi penelitian yaitu mencangkup semua sektor perusahaan yang terdaftar di Bursa Efek Indonesia. Penelitian selanjutnya juga dapat menggunakan indikator pengukuran lainnya seperti Return on Equity, Tobin's Q, PER dan lain sebagainya.

\section{REFERENSI}

Afzal dan Rohmah. 2012. Pengaruh Keputusan Investasi Keputusan Pendanaan dan Kebijakan Dividen Terhadap Nilai Perusahaan.Jurnal Akuntansi Universitas Diponegoro.

Anggitasari, N. dan S. Mutmainah. 2012. Pengaruh kinerja Keuangan Terhadap Nilai Perusahaan Dengan Pengungkapan Corporate Social Responsibility Dan Struktur Good Corporate Governance Sebagai Variabel Moderasi. Jurnal Akuntansi, Vol. 1, No.2.

Anwar, Samsinar. 2010. Pengaruh Pengungkapan Corporate Social Responsibility Terhadap Kinerja Keuangan Perusahaan dan Harga Saham.Jurnal Ekonomi.

Crisóstomo, Vicente Lima dan Freire, Fátima de Souza dan Vasconcellos, Felipe Cortes de . 2012. Corporate Social Responsibility, Firm Value and Financial Performance in Brazil. Social Responsibility Journal, Vol. 7 Issue: 2, pp.295-309, 
Dahlia, L. dan Siregar, V. S. 2008. Pengaruh Corporate Social Responsibility terhadap Kinerja Perusahaan (Studi Empiris pada Perusahaan yang tercatat di Bursa Efek Indonesia pada Tahun 2005 dan 2006).Simposium Nasional Akuntansi XI. Pontianak.

Deriyarso, Irvan. 2014. Pengaruh Profitabilitas terhadap Nilai Perusahaan dengan Corporate Social Responsibility sebagai Variabel Moderating. Thesis. Universitas Diponegoro.

Dilling. 2009. “ Sustainability Reporting In A Global Context: What Are The Characteristics Of Corporatons That Provide High Quality Sustainability Reports-An Empirical Analysis." International Business \& Economics Research Journal.Vol.9, No.1.New York Institute of Technology. Canada.

Ekowati, Lilis. 2014. Pengaruh Profitabilitas, Likuiditas, Growth dan Media Exposure Terhadap Pengungkapan Tanggungjawab Sosial Perusahaan (Studi pada Perusahaan Manufaktur yang Terdaftar di BEI Tahun 20102012). Simposium Nasional Akuntansi XVII Madura.

Febriana, Elia. 2016. Pengaruh Struktur Modal, Kebijakan Dividen, Ukuran Perusahaan, Kepemilikan Saham Manajerial dan Profitabilitas Terhadap Nilai Perusahaan. Jurnal Ekonomi Bisnis.No.2

Hau ,LeLong dan Luu Chi Danh. 2017. Determinants of Corporate Disclosure in Financial Statements: Evidence from Vietnamese Listed Firms. International Journal of Advanced Engineering, Management and Science (IJAEMS), Vol-3, Issue-5,ISSN: 2454-1311

Hidayansyah, Putri Fika. 2015. Pengaruh Pengungkapan Corporate Social Responsibility terhadap Kinerja Keuangan dan Harga Saham pada Perusahaan Sektor Properti di Bursa Efek Indonesia. Jurnal Bogor: Institut Pertanian Bogor.

Ika Fanindya Jusriani dan Shidiq Nur Rahardjo, 2013.Analisis Pengaruh Profitabilitas, Kebijakan Dividen, Kebijakan Utang, Dan Kepemilikan Manajerial Terhadap Nilai Perusahaan (Studi Empiris Pada Perusahaan Manufaktur Yang Terdaftar Di Bursa Efek ).Jurnal Manajemen.

Jogiyanto, Hartono. 2013. Teori Portofolio dan Analisis Investasi. Edisi 8. Yogyakarta:BPFE.

Kasmir. (2010). Pengantar Manajemen Keuangan.Jakarta: Kencana Prenada Media Group. 
Lako, Andreas. 2010. Dekonstruksi CSR dan Reformasi Paradigma Bisnis dan Akuntansi. Jakarta:Erlangga.

Maryam dkk.2012.Pengaruh Karakteristik Perusahaan Terhadap Keberadaan Pengungkapan Dalam Laporan Tahunan Sektor Properti Yang Terdaftar Di Bursa Efek Indonesia. Jurnal Akuntansi. ISSN 2302-0164. Volume 2, No.1, November 2012. Pages pp. 86- 99. Pascasarjana Universitas Syiah Kuala.

Munawaroh, A., \& Priyadi, M. P. (2014).Pengaruh Profitabilitas Terhadap Nilai Perusahaan dengan Corporate Social Responsibility Sebagai Variabel Moderasi.Jurnal Manajemen.

Nurlela, Rika,dan Islahudin. 2008. "Pengaruh Corporate Social Responsibility Terhadap Nilai Perusahaan dengan Prosentase Kepemilkan Manajerial Sebagai Variabel Moderasi”. Simposium Nasional Akuntansi. Pontianak.

Pratama ,I Gusti Bagus Angga. 2016. Pengaruh Ukuran Perusahaan Dan Leverage Terhadap Nilai Perusahaan Dengan Profitabilitas Sebagai Variabel Mediasi. E-Jurnal Manajemen Unud.Vol.5.No. 2. ISSN: 2302-8912.

Priatinah,Denies dan Prabandaru Adhe Kusuma. 2012. Pengaruh Return On Investment (ROI),Earning Per Share (EPS),dan Dividen Per Share (DPS) Terhadap Harga Saham Perusahaan Pertambangan yang Terdaftar di BEI Periode 2008-2010. Universitas Negeri Yogyakarta,Yogyakarta.Jurna Manajemen dan Bisnis .

Putra, C. B. P., dan A. Prastiwi. 2013. Pengaruh Karakteristik Perusahaan Terhadap Pengungkapan Tanggung Jawab Sosial Pada Perusahaan Manufaktur Yang Terdaftar di Bursa Efek Indonesia. Jurnal Ilmiah Mahasiswa FEB.Vol 1, No 1.

Putri, Ayu Oktyas dan Suwitho. 2015. Pengaruh Kinerja Keuangan Terhadap Nilai Perusahaan Dengan Pengungkapan Csr Sebagai Variabel Pemoderasi. Jurnal Ilmu dan Riset Manajemen, Vol. 4, No. 4.

Rahayu, Sri. 2010. "Pengaruh Kinerja Keuangan terhadp Nilai perusahaan denganPengungkapan Corporate Social Responsibility dan Good Corporate Governance sebagai Variabel Pemoderasi".Jurnal Manajemen dan Bisnis .Universitas Diponegoro. 
Ramdana, Rizki. 2017. Pengaruh ROE, NPM, Terhadap Harga Saham Dengan Pengungkapan CSR Sebagai Variabel Moderasi. Jurnal Ilmu \& Riset Manajemen, Vol. 6, No. 9.

Rakhiemah, Aldilla Noor dan Dian Agustia. 2009, “Kinerja Lingkungan Terhadap Corporate Social Responsibility (CSR)Disclosure dan Kinerja Finansial Perusahaan Manufaktur Yang Terdaftar di Bursa Efek Indonesia”, Universitas Airlangga.

Setiabudi, Andi., dan Dian Agustia. 2012. "Fundamental Factor of Firm due to the Firm Value".Journal of Basic and Applied Scientific Research.ISSN 20904304.

Sumiati , Siti Aisjah dan Dwita Ayu Rizqia.2013."Effect of Managerial Ownership, Financial Leverage, Profitability, Firm Size, and Investment Opportunity on Dividend Policy and Firm Value". Research Journal of Finance and Accounting Vol.4, No.11.

Timbuleng, F., Nangoy, S. C., dan Saerang, I. S. 2015. Pengaruh faktor Likuiditas, Leverage, NPM, dan ROI terhadap Nilai Perusahaan (Studi pada Perusahaan Consumer Goods yang Terdaftar di Bursa Efek Indonesia Periode 2010-2013). Jurnal EMBA, Vol. 3, No. 2,pp. 546-557.

Triagustina, L., Sukarmanto, E., \& Helliana. 2015. Pengaruh Return On Asset (ROA) Dan Return On Equity (ROE) Terhadap Nilai Perusahaan Pada Perusahaan Manufaktur Subsektor Makanan Dan Minuman Yang Terdaftar Di Bursa Efek Indonesia Periode 2010-2012. Prosiding Akuntansi, ISSN: 2460-6561.

Untung, Hendrik Budi, 2015.Corporate Social Responbility, Jakarta: Sinar Grafika.

Utami, Sri dan Prastiti, Sawitri Dwi. 2011.Pengaruh Karakteristik Perusahaan terhadap Social Disclosure.Jurnal Ekonomi Bisnis, No.1.

Wijaya, Anthony dan Linawati, Nanik. 2015. Pengaruh Kinerja Keuangan terhadap Nilai Perusahaan. FINESTA, Vol. 3. pp: 46-51

Wulandari, Ni Made Intan dan Wiksuana, I Gusti Bagus. 2017. Peranan Corporate Social Responsibility Dalam Memoderasi Pengaruh Profitabilitas, Leverage Dan Ukuran Perusahaan Terhadap Nilai Perusahaan. E-Jurnal Manajemen Unud, Vol. 6, No. 3, ISSN : 2302-8912. 
Ni Kadek Raningsih, dan Luh Gede Sri Artini. Pengaruh Profitabilitas .....

Yuliani, Nurbaity. 2014., “ Pengaruh Struktur Kepemilikan Saham dan Karakteristik Perusahaan terhadap Pengungkapan Corporate Social Responsibilitypada Perusahaan Pertambangan yang Terdaftar di BEI Tahun 2011-2013”. Tesis. Denpasar: Universitas Udayana.

Zuraedah, Isnaeni Ken. 2010. "Pengaruh Kinerja Keuangan Terhadap Nilai Perusahaan dengan Pengungkapan Corporate Social Respontibility Sebagai Variabel Pemoderasi.Jurnal Ekonomi. Universitas Pembangunan Nasioanal Veteran, Jakarta. 